\title{
Acute hepatitis induced by alpha-interferon in a patient with chronic hepatitis $\mathrm{C}$
}

\author{
Ivan Kraus $\mathrm{MD} \mathrm{PhD}^{1}$, Dinko Vitezic $\mathrm{MD} \mathrm{PhD}^{2}$
}

I Kraus, D Vitezic. Acute hepatitis induced by alpha-interferon in a patient with chronic hepatitis C. Can J Gastroenterol 2001;15(5):333-335. Hepatic adverse effects occur very rarely with alpha-interferon therapy. A case of acute hepatitis induced by alpha-interferon in a 33-year-old man with chronic hepatitis $\mathrm{C}$ is described. The patient developed acute hepatitis with very high aminotransferase activity and jaundice. After discontinuing alpha-interferon therapy, hepatitis resolved rapidly. The immune-mediated mechanism is the most probable cause of this hepatitis.

Key Words: Acute hepatitis; Alpha-interferon; Chronic hepatitis C; Therapy

\section{Hépatite aiguë causée par l'interféron alpha chez un patient atteint d'hépatite $\mathrm{C}$ chronique}

RÉSUMÉ : Le traitement à l'interféron alpha produit très rarement d'effets indésirables sur le foie. Voici un cas d'hépatite aiguë causée par l'interféron alpha chez un homme de 33 ans atteint d'hépatite $\mathrm{C}$ chronique. La forme aiguë était accompagnée d'ictère et d'une hausse très marquée de l'activité des transaminases. L'hépatite s'est résorbée rapidement, après l'arrêt du traitement à l'interféron alpha. Elle est probablement due à un mécanisme lié aux défenses immunitaires.

\begin{abstract}
A lpha-interferon is a standard therapy for chronic hepatitis $\mathrm{C}$ virus (HCV) infection (1-3). Aminotransferase activity is known to be elevated in patients receiving interferon for the treatment of carcinoma (4) or chronic B or C viral hepatitis $(5,6)$. The present report describes a case of acute hepatitis with a marked elevation of aminotransferase activity and jaundice during the treatment of chronic hepatitis $\mathrm{C}$ with alpha-interferon.
\end{abstract}

\section{CASE PRESENTATION}

A 33-year-old man with positive anti-HCV antibodies was examined as an outpatient due to persistently high aminotransferase activity during the previous year. The initial biochemical values on September 17, 1996 were: serum alanine aminotransferase $272 \mathrm{IU} / \mathrm{L}$ (normal less than $30 \mathrm{IU} / \mathrm{L}$ ), serum aspartate aminotransferase $184 \mathrm{IU} / \mathrm{L}$ (normal less than $30 \mathrm{IU} / \mathrm{L}$ ), serum alkaline phosphatase $97 \mathrm{IU} / \mathrm{L}$

\footnotetext{
${ }^{1}$ Department of Gastroenterology, University Hospital Centre Rijeka, Rijeka, Croatia; ${ }^{2}$ Department for Science and Clinical Pharmacology, University Hospital Centre Rijeka, and Department of Pharmacology, University of Rijeka Medical School, Rijeka, Croatia

Correspondence: Dr Dinko Vitezic, Department for Science and Clinical Pharmacology, University Hospital Centre Rijeka,

and Department of Pharmacology, Univerisity of Rijeka Medical School, Brace Branchetta 20, 51000 Rijeka, Croatia.

Telephone +385-51-651-179, fax +385-51-651-174, e-mail: Dinko.Vitezic@mamed.medri.hr

Received for publication March 14, 2000. Accepted July 14, 2000
} 


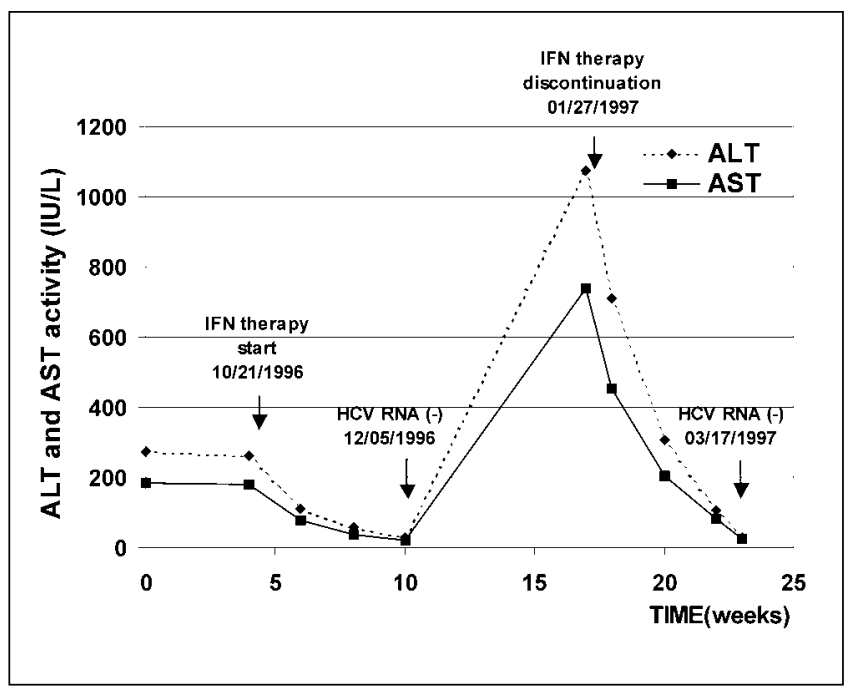

Figure 1) Alanine aminotransferase (ALT) and aspartate aminotranferase (AST) levels in a patient with chronic hepatitis C. The arrows show the dates of the start and discontinuation of alpha-interferon therapy, as well as the dates of hepatitis $\mathrm{C}$ virus (HCV) RNA negative (-) tests. IFN Interferon

(normal less than $90 \mathrm{IU} / \mathrm{L}$ ), gamma-glutamyl transferase $93 \mathrm{IU} / \mathrm{L}$ (normal less than $35 \mathrm{IU} / \mathrm{L}$ ), serum albumin $41 \mathrm{~g} / \mathrm{L}$ (normal 35 to $50 \mathrm{~g} / \mathrm{L}$ ) and gamma-globulin $13 \mathrm{~g} / \mathrm{L}$ (normal 5 to $15 \mathrm{~g} / \mathrm{L}$ ); prothrombin activity was $93 \%$ of normal, and total bilirubin was $12.3 \mu \mathrm{mol} / \mathrm{L}$ (normal 5 to $17 \mu \mathrm{mol} / \mathrm{L}$ ). The patient had never undergone any surgery and had never had any transfusions of blood or blood products.

The patient was not a drug user and had no other risk factors for hepatitis C. It is not known how the patient acquired hepatitis C. All of the hepatitis B markers were negative, as were antinuclear antibody, antimitochondrial antibody, antismooth muscle antibody and antiliverkidney microsomes type 1 (LKM-1) antibody. Alpha-1antitripsin, copper, ceruloplasmin, iron, transferrin and ferritin levels were also normal.

The patient was positive for anti-HCV antibodies (by ELISA 3 and recombinant immunoblot assay 3). Tests for HCV RNA were positive by reverse transcriptase polymerase chain reaction, with $10.7 \times 10^{6}$ copies of $\mathrm{HCV}$ $\mathrm{RNA} / \mathrm{mL}$. The patient's genotype was $1 \mathrm{~b}$. Clinical examinations were normal. Ultrasound examination of the liver, gallbladder and pancreas was also normal. Liver biopsy showed chronic hepatitis of moderate activity, with a staging score of 10 and a grading score of $2(7,8)$.

The treatment with alpha2b-interferon was started at a dose of $3 \times 10^{6} \mathrm{U}$ three times per week (October 21, 1996). Within six weeks, aminotransferase activity became normal, and tests for HCV RNA were negative (December 5, 1996). After three months of therapy, the patient developed malaise, with painful muscles and joints, a subfebrile temperature and jaundice. The biochemical values at this time were: bilirubin $277 \mu \mathrm{mol} / \mathrm{L}$, alanine aminotransferase $1075 \mathrm{IU} / \mathrm{L}$, aspartate aminotransferase $740 \mathrm{IU} / \mathrm{L}$, alkaline phosphatase $111 \mathrm{IU} / \mathrm{L}$ and gamma-glutamyl transferase $143 \mathrm{IU} / \mathrm{L}$; pro- thrombin activity was $71 \%$ of normal (January 24,1997 ). Throughout alpha-interferon therapy, the patient did not consume any alcohol or take medication of any kind. The patient developed a very mild influenza-like syndrome during therapy and did not take acetaminophen or any other nonsteroidal anti-inflammatory agents.

The results of testing for immunoglobulin M (IgM)-specific hepatitis A virus antibody, IgM-specific hepatitis B core antibody, hepatitis B virus DNA, hepatitis B surface antigen, IgM hepatitis $\mathrm{E}$ virus antibody and hepatitis $\mathrm{G}$ virus RNA were negative. Serological testing for EbsteinBarr virus, cytomegalovirus and herpesviruses was also negative. Antinuclear antibody, antimitochondrial antibody, antismooth muscle antibody and anti-LKM-1 test results were negative in three performed analyses.

The second abdominal ultrasound was normal, as were the abdominal computed tomography scan and colour Doppler. Tests for HCV RNA were negative with reverse transcriptase polymerase chain reaction. The second liver biopsy showed marked portal, periportal and intralobular lymphocytic infiltration with hepatocellular necrosis. The hepatocytes showed massive foci of necrosis with surrounding collapse, and there were also some fatty changes of hepatocytes. Surviving liver cells retained their glycogen, and the sinusoids showed mononuclear cellular infiltration. Bile duct proliferations and damage were also present. The reticulin framework was well preserved. It was believed that the patient had acute hepatitis caused by alpha-interferon, and the therapy was discontinued on January 27, 1997. Serum aminotransferase activities decreased rapidly, and after six weeks, jaundice disappeared, aminotransferase activity normalized, and tests for HCV RNA remained negative (March 17, 1997) (Figure 1).

At 36 months' follow-up, the aminotransferase activity remained normal, and tests for HCV RNA were negative.

\section{DISCUSSION}

We believe that alpha-interferon caused acute hepatitis in this patient. No positive serology for acute hepatitis (A, B, E and G), cytomegalovirus, Ebstein-Barr or herpes was found. Moreover, the patient neither abused alcohol nor took any drugs besides interferon, thus excluding these as possible causes of acute hepatitis. Autoantibodies, another possible cause, were not found, so they were excluded as a cause. Anti-interferon antibodies were also not detected. Hepatotropic viruses and some other viruses, as well as exacerbation of autoimmune hepatitis, were excluded as causes, although non-A, non-E acute hepatitis could not be ruled out.

A very important argument for interferon therapy being responsible for the acute hepatitis in this case is the rapid normalization of aminotransferase activity after treatment was stopped. The mechanism responsible for the development of acute hepatitis during interferon therapy is not easily explained. Toxic effects of interferon on hepatocytes or an immunologically mediated mechanism are possible theoretical explanations (9). 
It is well known that high doses of interferon can cause hepatic necrosis in mice. Baglioni (10) explained that interferon could induce a marked decrease in protein synthesis, as well as inhibition of several enzymes, such as $2^{\prime} 5^{\prime}$ oligoadenylate synthetase and protein kinase. At the same time, interferon decreases the transcription of mitochondrial DNA and impairs fatty acid beta-oxidation. All of these changes lead to hepatocyte injury.

Itoh et al (11) showed the ultrastructural change of hepatocytes in patients receiving interferon for chronic hepatitis B. A marked decrease in the number of mitochondria, as well as alterations of endoplasmic reticulum and fat vacuoles, were seen in their patients. These changes suggest decreased fatty acid oxidation.

There are many arguments against the toxic effects of interferon, including the fact that a very large number of patients are treated with interferon, and only a very small number of them developed toxic effects. Another argument is that the occurrence of hepatitis is not dose-related. Our patient had no microvesicular steatosis, which is the characteristic lesion when fatty acid beta-oxidation is inhibited, and marked lymphocytic infiltration was present (12).

We are inclined to believe that an interferon-induced, immune-mediated mechanism underlies the acute hepatitis seen in our patient. Although such a reaction is not common during the treatment of chronic hepatitis $\mathrm{C}$, it may, however, be considered possible. For example, after several months of interferon therapy in patients with chronic hepatitis $B$, the illness is exacerbated almost regularly, ie, aminotransferase activity increases suddenly, reflecting immune-mediated lysis of hepatocytes and the elimination of $B$ viruses due to an enhanced cellular immune response. The occasional exacerbation of autoimmune chronic hepatitis in patients with positive antismooth muscle antibodies or anti-LKM-1 antibodies supports this type of reaction (13-15). It could, therefore, be assumed that this is also possible in hepatitis $\mathrm{C}$.

\section{CONCLUSIONS}

In the absence of other causes, the present report of a patient with chronic hepatitis $\mathrm{C}$ suggests that there is a strong relationship between acute hepatitis and alpha- interferon treatment. The most probable mechanism is an excessive immune response to $\mathrm{HCV}$, but it is not clear whether this excessive immune response contributes to the elimination of HCV. Further clinical investigations of similar cases are required to clarify the mechanism involved in the development of this type of hepatitis and its role in the elimination of HCV from the body.

\section{REFERENCES}

1. Hoofnagle JH. Therapy of viral hepatitis. Digestion 1998;59:563-78

2. Moussalli J, Opolon P, Poynard T. Management of hepatitis C. J Viral Hepat 1998;5:73-82

3. Keeffe EB, Hollinger FB. Therapy of hepatitis C: consensus interferon trials. Consensus Interferon Study Group. Hepatology 1997;26(Suppl 1):101-7.

4. Wandl UB, Kloke O, Nidierle N. Liver failure due to recombinant alpha interferon for chronic myelogenous leukaemia. Lancet 1992;339:123-4.

5. Shindo M, Di Bisceglie AM, Hoofnagle JH. Acute exacerbation of liver disease during interferon alpha therapy for chronic hepatitis C. Gastroenterology 1992;102:1406-8.

6. Marcellin P, Colin J-F, Boyer N, et al. Fatal exacerbation of chronic hepatitis B induced by recombinant alpha-interferon. Lancet 1991;338:828

7. Knodell RG, Ishak KG, Block WC, et al. Formulation and application of a numerical scoring system for assessing histological activity in asymptomatic chronic active hepatitis. Hepatology 1981;1:431-5.

8. Desmet VJ, Gerber M, Hoofnagle JH, Manns M, Scheuer PJ. Classification of chronic hepatitis: diagnosis, grading and staging. Hepatology 1994;19:1513-20.

9. Cervoni J-P, Degos F, Marcellin P, Erlinger S. Acute hepatitis induced by alpha-interferon, associated with viral clearance, in chronic hepatitis C. J Hepatol 1997;27:1113-6.

10. Baglioni C. Interferon induced enzymatic activities and their role in antiviral state. Cell 1979;17:255-64.

11. Itoh S, Marutani K, Matsuo S. Changes in ultrastructure of hepatocytes and liver tests results before, during, and after treatment with interferon- $\beta$ in patients with $\mathrm{HBeAg}$-positive chronic active hepatitis. Dig Dis Sci 1992;37:1260-7.

12. Fromenty B, Pessayre D. Inhibition of mitochondrial beta-oxidation as a mechanism of hepatotoxicity. Pharmacol Ther 1995;67:101-54.

13. Farhat BA, Johnson PJ, Williams R. Hazard of interferon treatment in patients with autoimmune chronic active hepatitis. J Hepatol 1994;20:560-1.

14. Muratori L, Lenzi M, Cataleta M, et al. Interferon therapy in liver/kidney microsomal antibody type 1-positive patients with chronic hepatitis C. J Hepatol 1994;21:199-203.

15. Papo T, Marcellin P, Bernuau J, Durand F, Poynard T, Benhamou J-P. Autoimmune chronic hepatitis exacerbated by alpha-interferon. Ann Intern Med 1992;116:51-3. 


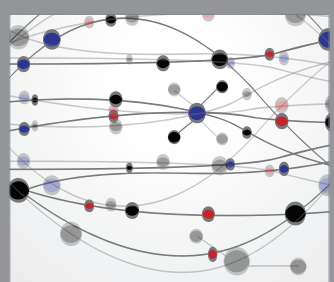

The Scientific World Journal
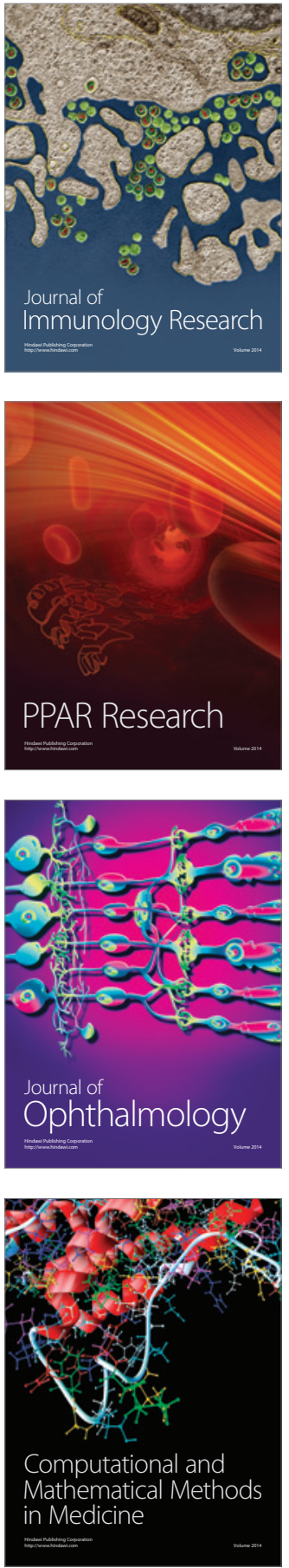

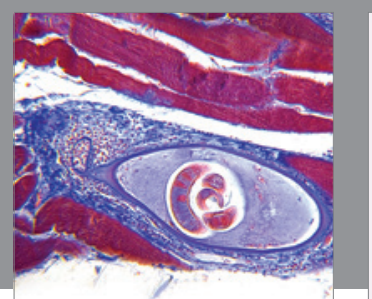

Gastroenterology Research and Practice

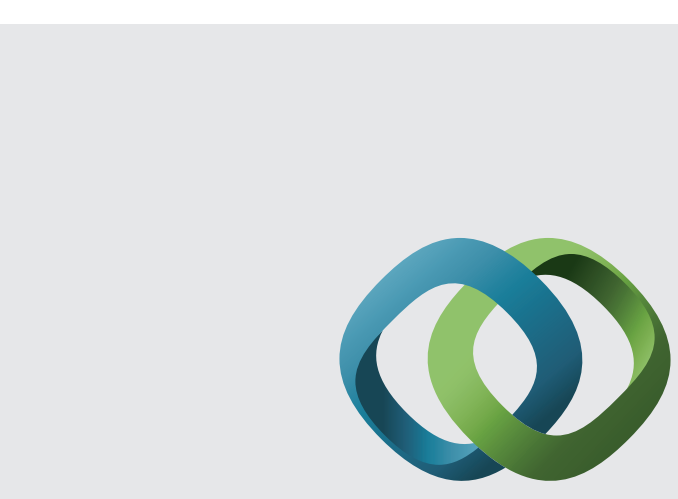

\section{Hindawi}

Submit your manuscripts at

http://www.hindawi.com
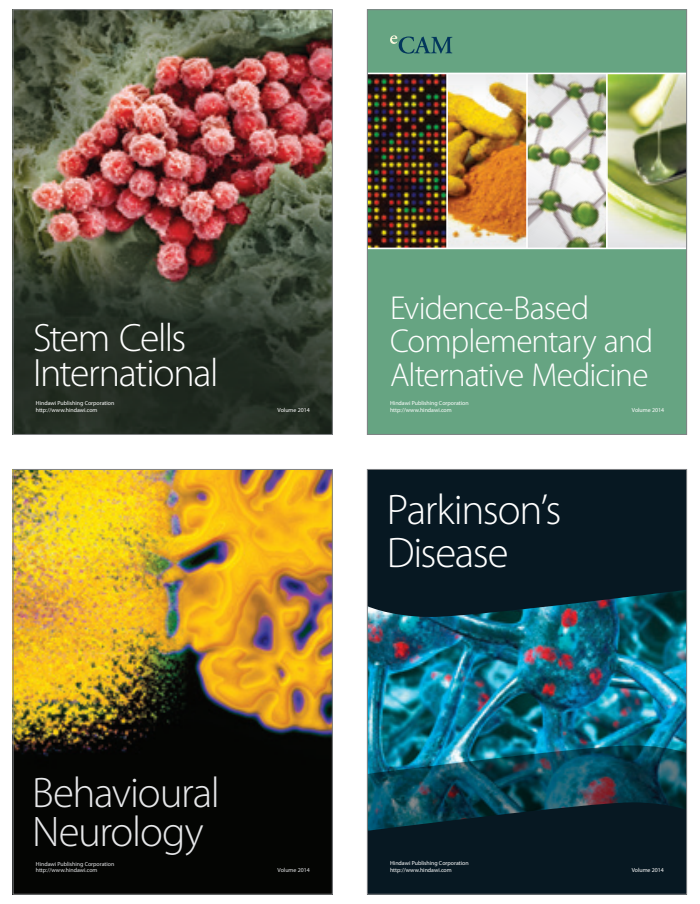
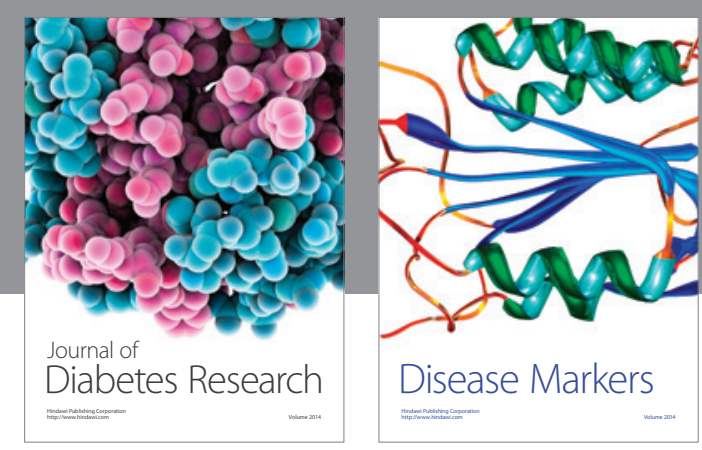

Disease Markers
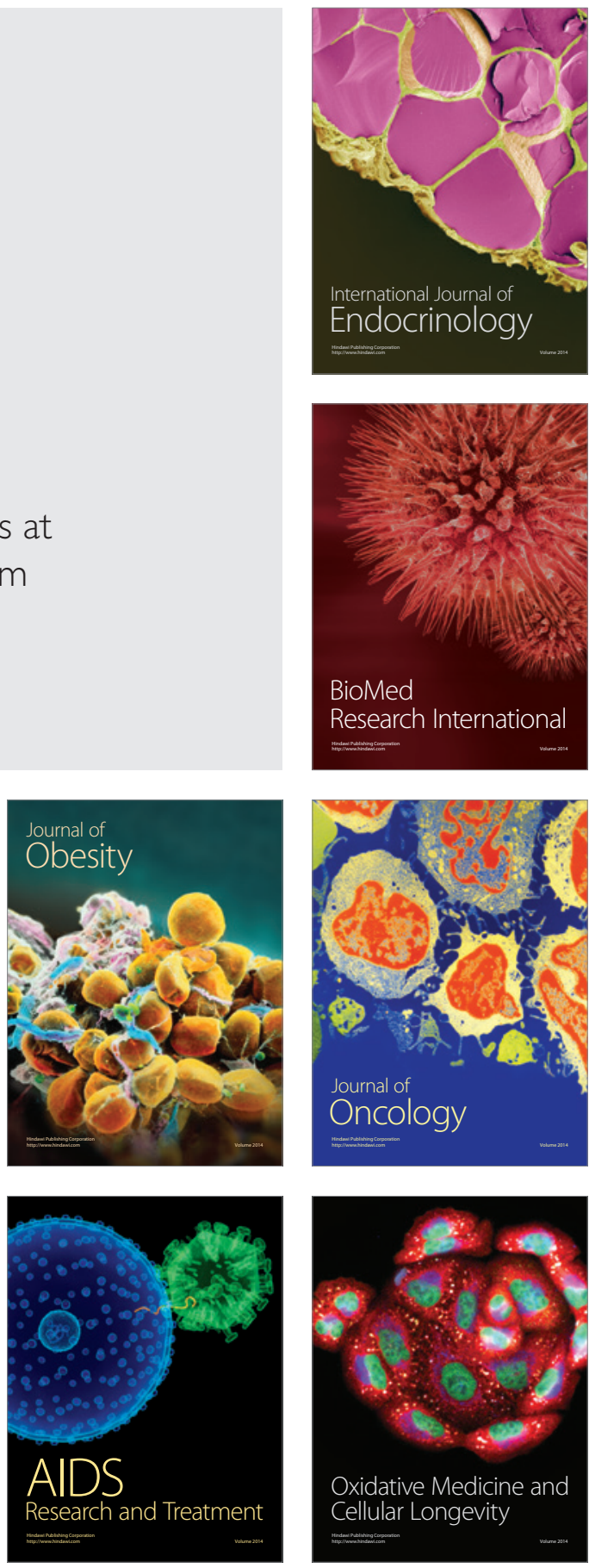